\title{
Distribution of chlorides and sulfates in the aeration zone of coal waste landfill - sulfides decomposition kinetics and ground water acidification
}

\author{
M. Gwozdziewicz \\ Central Mining Institute, Katowice, Poland
}

\begin{abstract}
This article presents the chemistry of deposited mining wastes in the Debiensko (Upper Silesia, Poland) coal mine as well as the process and dynamics of pollutants released from the wastes located in this landfill. The main stages of migration in the water solution have been emphasized as well as changes of chemistry and the dynamics of their spreading. The article also shows the impact of pollution both in the aeration zone and upon surface and underground water in the area of landfill. It was stated that the level of water degradation caused by depositing of coal wastes is high and it is related to chlorides and sulfates and in the last phase of rock weathering - with iron.

Keywords: migration of pollutants, chlorides and sulfates, sulfide oxidation.
\end{abstract}

\section{Introduction}

The most voluminous group of wastes produced in Poland are wastes generated during search, mining, physical and chemical treatment of ores and other fossils. Wastes from power generation fossil mining constitute ca 29\% [2] of the overall production of wastes in Poland. Development of forecasting methods for the impact of coal mining waste landfills upon underground water are very numerous but they often yield different results. In spite of the fact that each mining waste landfill features different depositing and hydro-geological properties as well as types of waste, we may find some common features for all deposited wastes. For this reason, the article presents results of a simulation of pollutants' transport in the aeration zone as well the kinetics of distribution of iron sulfides using the mining waste landfill "Debiensko" as an example. 


\section{Characteristics of the facility}

The mining waste landfill of KWK "Debiensko" is located within Silesia Uplands, within the municipality area of Czerwionka-Leszczyny, in the northeastern part of city of Czerwionka, in the drainage area of Jordanek stream - an effluent of the Bierawka river joining the Odra river. This landfill, with its total area of 140 ha is of upper-level character. The landfill "Debiensko" under investigation has accommodated ca 37 millions of $\mathrm{Mg}$ of coal wastes [1]. The age of the deposited wastes is over 25 years. From the northern side this landfill is limited by the Jordanek stream valley; from the east by Furgol Street and from the west by Markwioka and Przemyslow Streets and land belonging to the "Debiensko" coal mine. On the south-west and west of the landfill body, there exists an unnamed ditch discharging leakage water (Fig. 1). Further, the landfill is limited by industrial areas.

The land ordinates in the landfill area oscillate from $250,0 \mathrm{~m}$ a.s.1. in the north-western part to $264,0 \mathrm{~m}$ a.s.1. in the eastern part. In this area sludge deposit tanks now being subject to the coal recovery process there are also located.

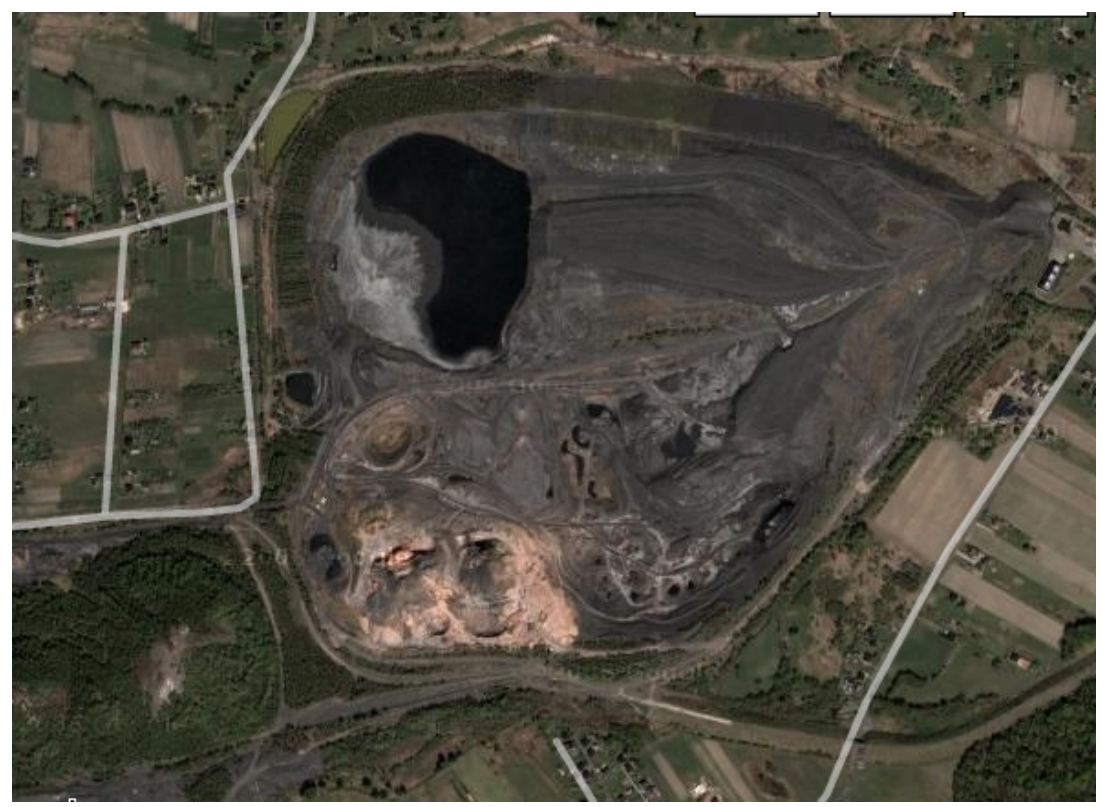

Figure 1: General view of coal waste landfill "Debiensko" (Silesia, Poland).

\section{Mineralogical and physico-chemical characteristics of wastes deposited in the "Debiensko" landfill}

The coal wastes deposited in the "Debiensko" landfill constitute mining and processing wastes. Mining wastes appear in the form of shale clays laminated 
with hard coal, claystones, mudstones, small quantities of sandstones and sporadic siderites from mudstone and the Upper Silesia sandstone series. The most frequent materials in the composition of weathered rock are quartz, kaolinite and mica, and in small quantities there are also feldspars, siderite, chlorite, smectite, illite and pyrite. This mineral composition is supplemented by an amorphous substance consisting mainly of iron hydroxides and in the case of carbonaceous shales an organic substance [1] (Table 1).

Processing wastes from coal enrichment processes that are deposited in this landfill are mainly claystones and mudstones. The deposits of the lowest fraction frequently feature the occurrence of an organic substance in the form of pulverized coal, in quantities up to $27 \%$ [1]. Mining wastes feature humidity from $4,8 \%$ to $7,6 \%$ and ash contents in the range from $63,4 \%$ to $83,8 \%$.

Examples of results of water extract tests made on wastes deposited in the landfill are presented in Table 2.

Table 1: $\quad$ Mineralogical composition of coal waste rock in the landfill (in \% of volume).

\begin{tabular}{|l|c|c|c|c|}
\hline \multicolumn{1}{|c|}{$\begin{array}{c}\text { Mineral } \\
\text { composition }\end{array}$} & \multicolumn{4}{c|}{ Rock type } \\
\hline & $\begin{array}{l}\text { Carbonaceous } \\
\text { shale }\end{array}$ & Claystone & Mudstone & Sandstone \\
\hline Quartz & 12 & 22 & 33 & 62 \\
\hline Mica & 17 & 21 & 19 & 13 \\
\hline Kaolinite & 21 & 23 & 26 & 15 \\
\hline Feldspar & 4 & 5 & 4 & 5 \\
\hline Pyrite & 3 & 2 & 2 & 1 \\
\hline Siderite & 6 & 4 & 5 & 3 \\
\hline Chlorite Smectite & 6 & 5 & 2 & $<1$ \\
\hline Amorphous subst. & 30 & 18 & 9 & $<1$ \\
\hline
\end{tabular}

Table 2: $\quad$ Physico-chemical analysis of water extracts from mining wastes.

\begin{tabular}{|c|c|c|c|c|}
\hline Parameter & Unit & Scrubber stone & Flotation wastes & Mud sludge \\
\hline $\mathrm{pH}$ & \multirow{12}{*}{$\mathrm{mg} / \mathrm{l}$} & 8,8 & 7,8 & 8,0 \\
\hline \begin{tabular}{|l|} 
NNH4 \\
\end{tabular} & & 1,62 & 0,66 & 0,42 \\
\hline NNO3 & & 0,55 & 0,33 & 0,22 \\
\hline $\mathrm{Cl}-$ & & 44,0 & 174,0 & 370,0 \\
\hline SO42- & & 139,0 & 349,0 & 154,0 \\
\hline $\mathrm{Cd}$ & & 0,001 & 0,001 & 0,001 \\
\hline $\mathrm{Cr}$ & & 0,01 & 0,01 & 0,01 \\
\hline $\mathrm{Cu}$ & & 0,01 & 0,02 & 0,01 \\
\hline $\mathrm{Fe}$ & & 0,10 & 0,10 & 0,10 \\
\hline $\mathrm{Mn}$ & & 0,01 & 0,02 & 0,01 \\
\hline $\mathrm{Pb}$ & & 0,03 & 0,01 & 0,03 \\
\hline $\mathrm{Zn}$ & & 0,01 & 0,01 & 0,01 \\
\hline
\end{tabular}


Water extracts from three types of coal wastes tested feature alkaline reactions in the range from 7,8 to $8,8 \mathrm{pH}$ and low concentration of heavy metals. As far as anions are concerned, sulfates are washed out more intensively than chlorides, which is caused by very quick leaching of chlorides during the scrubbing process and in the first weeks of waste depositing. Scrubbing out of sulfates is a slower and more complex process than chloride leaching [1]. The process and dynamics of sulfide oxidation in the landfill will be presented later in this article.

Data concerning the volume of sulfates and chlorides as the load of pollutants washed out from carbonaceous wastes are supplemented by lysimetric tests. The values of pollutants' loads are recalculated into concentrations in the solution filtered off the lysimeter (Table 3) [1].

Table 3: $\quad$ Results of lysimetric tests of coal wastes.

\begin{tabular}{|l|l|l|l|l|l|}
\hline \multicolumn{1}{|c|}{ Wastes } & \multicolumn{1}{c|}{ Range } & \multicolumn{2}{c|}{ Chlorides } & \multicolumn{2}{c|}{ Sulfates } \\
\hline $\begin{array}{l}\text { (layer in m below } \\
\text { land level) }\end{array}$ & $\mathrm{pH}$ & $\begin{array}{l}\text { Load } \\
{[\mathrm{g}]}\end{array}$ & $\begin{array}{l}\text { Concentra- } \\
\text { tion }[\mathrm{mg} / \mathrm{l}]\end{array}$ & $\begin{array}{l}\text { Load } \\
{[\mathrm{g}]}\end{array}$ & $\begin{array}{l}\text { Concentra- } \\
\text { tion }[\mathrm{mg} / \mathrm{l}]\end{array}$ \\
\hline Fresh $(0,4)$ & $7,4-8,0$ & 1,051 & 534,0 & 0,766 & 389,3 \\
\hline Fresh $(0.8)$ & $7,9-8,6$ & 1,302 & 727,6 & 1,694 & 946,4 \\
\hline One year old $(0,8)$ & $7,4-8,2$ & 1,170 & 599,5 & 2,867 & 1468,7 \\
\hline Five year old $(0,8)$ & $6,9-7,5$ & 0,640 & 326,5 & 4,495 & 2293,3 \\
\hline
\end{tabular}

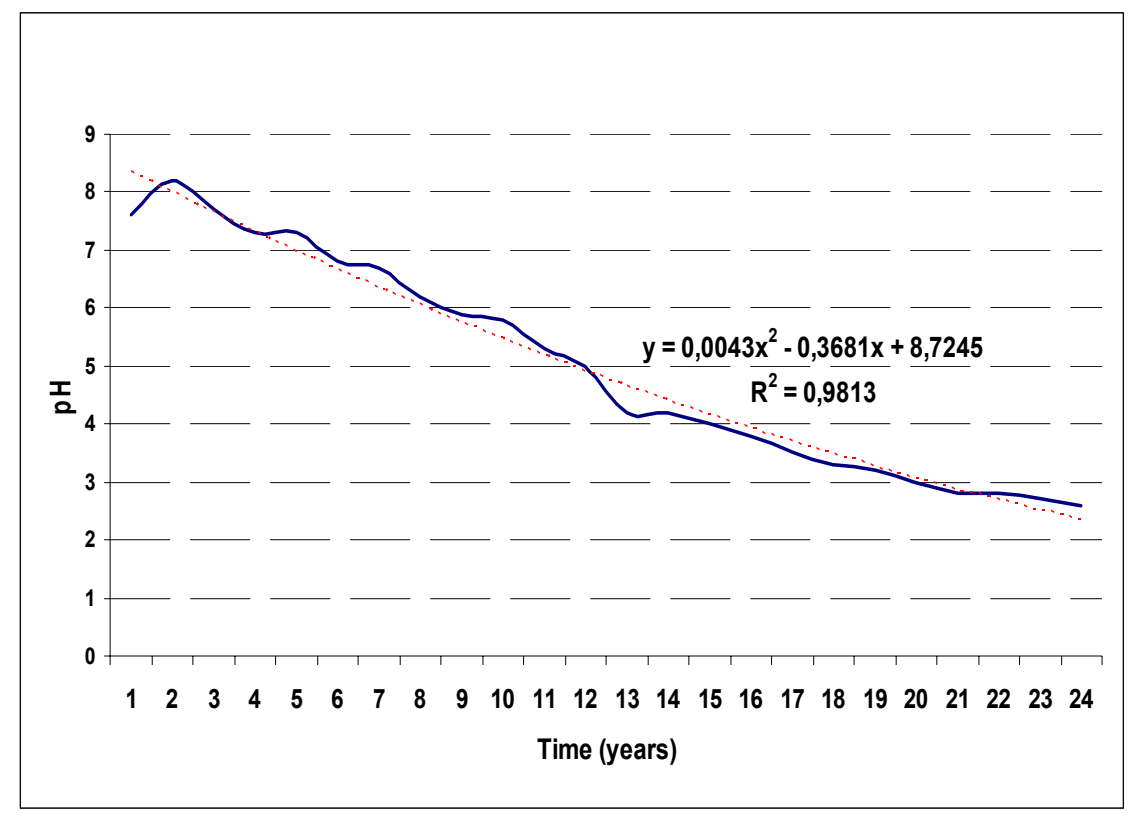

Figure 2: $\quad$ Simulation of $\mathrm{pH}$ changeability for the filtrates from coal waste landfill over time. 
The presented test results may lead to the conclusion that the leached quantities of chlorides have already dropped after the first year of washing the coal wastes with water. Only half of the chloride quantity washed out of fresh wastes is being washed out from the extracted material after five years. Whereas for washed out sulfates the observed tendency is quite the reverse.

From the wastes being washed during one year, the quantity of sulfate irons is half the quantity washed out from "fresh" wastes and over two times more than after five years of depositing. This phenomenon results from the process of moving sulfates generated by the weathering of iron sulfides (pyrite and marcasite) contained in carbonaceous coal wastes. This phenomenon also has the effect of unbalancing the eco-chemical balance of the waste depositing environment, caused by the quantitative edge of sulfates generated by the weathering of sulfides over the possibilities of their neutralization mainly by carbonate minerals (calcite, dolomite, siderite) [6]. In the case of quantitative advantage of sulfates released from the coal wastes, the outcome is most frequently acidification of the environment with all further consequences of this eco-chemical status. In the case of so called "fresh" wastes being investigated, the lysimetric filtrates have shown a slightly alkaline reaction with an acidification tendency of older filtrates (tab.3, Fig.2). This means a reduction of the buffering capacities of wastes under consideration after a period of 5 years from being deposited.

\section{Oxidation and decomposition of sulfides in the landfill}

The sulfur content in coal wastes originating from the "Debiensko" landfill is on average $1,41 \% \mathrm{Sc}$, including ca. $1,30-1,35 \% \mathrm{Sp}$ (sulfide or pyrite sulfur) [1]. The oxidation process of iron sulfides takes place in two stages, initially through oxidation of sulfur, then by oxidation of divalent iron:

$$
\mathrm{FeS} 2+7 / 2 \mathrm{O} 2+\mathrm{H} 2 \mathrm{O} \rightarrow \mathrm{Fe} 2++2 \mathrm{H}++2 \mathrm{SO} 42-
$$

and then

$$
\mathrm{Fe} 2++5 / 2 \mathrm{H} 2 \mathrm{O}+1 / 4 \mathrm{O} 2 \rightarrow \mathrm{Fe}(\mathrm{OH}) 3+2 \mathrm{H}+
$$

The course and speed of these chemical reactions depend mainly on the degree of crystallization of quantities of substitutions with other metals (such as $\mathrm{Mn}, \mathrm{Cu}$ or $\mathrm{As}$ ) in the crystalline grid and on the mineralogical form of the sulfides, largely depending as well on the availability of oxygen and water around the mineral grains. The oxidation reaction speed for sulfites is slowed down in the presence of calcite and dolomite and - to a lesser degree - also siderite. These minerals buffer acidification of coal wastes.

An additional factor speeding up the decomposition of sulfides in the coal wastes is the presence of micro-organisms, because the oxidation reaction of pyrite, and especially marcasite, takes place with their participation. The oxidation reaction takes place mainly in the aeration zone, where penetration of oxygen is possible. The process of sulfide leaching from coal wastes takes place in accordance with the equation of its range kinetics with the half-leaching time 
oscillating within a broad range from 29 to 10500 days with an average period of ca. 600 days. This process may be described with the following equation $[4,5]$ :

$$
\begin{array}{r}
\mathrm{Gs}(\mathrm{t})=\mathrm{Gs} 0 \cdot \mathrm{e}-\mathrm{k} \cdot \mathrm{t} \\
t=\frac{\ln \frac{G_{s}}{G_{0}}}{-k}
\end{array}
$$

where:

$\mathrm{Gs}(\mathrm{t})$ is the content of sulfide sulfur, in \% of weight, remaining in the coal wastes after time $\mathrm{t}$ (days) from the time of deposit (from the moment of contact with atmospheric conditions),

Gs0 is the content of sulfide sulfur, in \% of weight, at the moment of bringing the rock to the surface,

$\mathrm{k}$ is the Kinetic constant (day -1),

$\mathrm{t}$ is the time (days) counted from the time of deposit (from the moment of contact with atmospheric conditions),

The processes occurring within the wastes deposited on the landfill lead to significant reduction of $\mathrm{pH}$ of filtrates from the landfill, even below the value of 2. The product of landfill transformation is dissociated sulfuric acid that acidifies wastes and increased the quantity of sulfates in the solutions. The effect of reaction lowering is higher leaching and migration of other components, such as iron, manganese, copper and arsenic. A similar situation takes place in the case of 2- and 6-valent sulfur [4,5](Fig. 3)

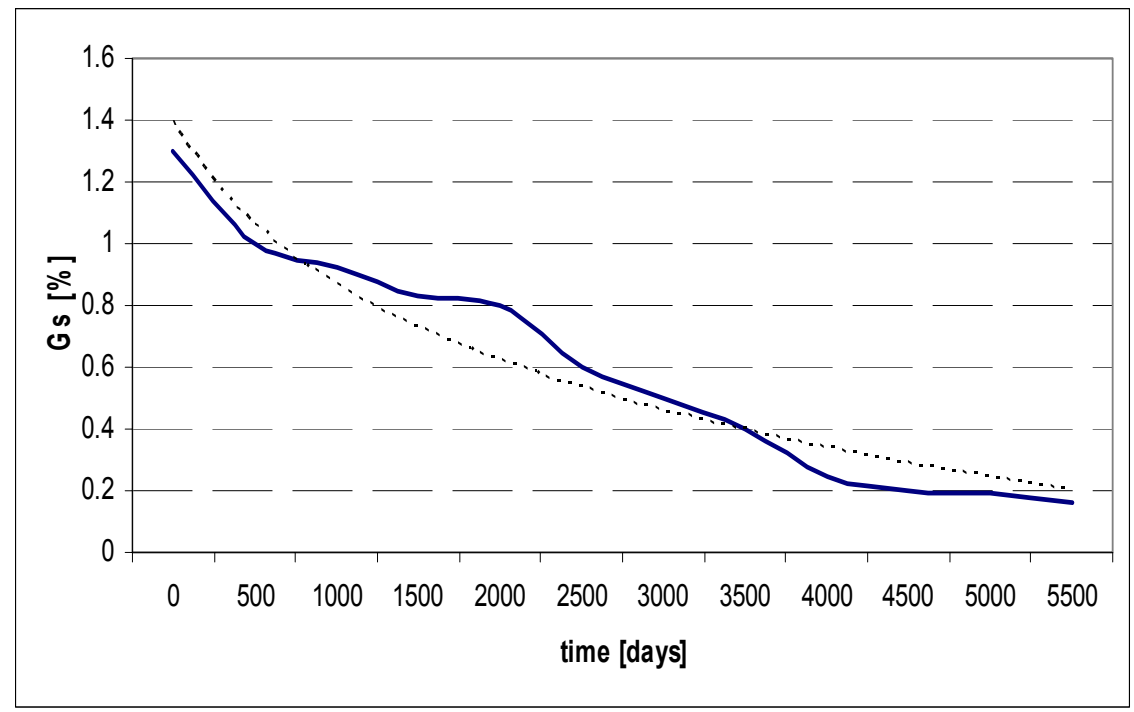

Figure 3: Kinetics of decomposition of sulfide sulfur leaching Gs(t) from coal mining wastes. 
An approximate solution of the sulfide decomposition course for the "Debiensko" landfill may be described in the following way: Gs(t) =0,01 - e $0,0005 \mathrm{t}$

\section{Conclusions}

1. In the first phase of water interaction on the coal wastes, chlorides are washed out and the water reaction in this phase is neutral or slightly alkaline. With time, the contamination with chlorides decreases, and increases contamination due to the weathering of sulfides. The increased quantity of migrating water with high concentration of sulfates occurs in the dumps with high water permeability of landfill's surface layer and is thermally active, as a result of precipitated oxidation of pyrite in the higher temperature.

2. Increased contents of sulfates results in the reduction of buffer capacity of deposited coal wastes as well as gradual lowering of $\mathrm{pH}$ of pore solutions and filtrates from the landfill.

3. Low reaction is due to the presence of non-dissociated sulfuric acid generated as a result of decomposition of pyrite and marcasite that intensifies the migration of metals, herein mainly iron and manganese.

4. Tests and simulations have shown a high degree of environment degradation of the soil and water environment, caused by an intensive decomposition of sulfides and the multi-year character of this phenomenon causes specific problems for the environment.

5. It is necessary to reduce the oxygen access to the inside of the landfill by compaction of the deposited material thus causing the reduction of water and oxygen inflow to the aeration zone of the landfill [3], which also reduces the threat of thermal activation of the facility to the minimum.

6. Creating a layer impermeable to water on the surface of deposited wastes by compacting the wastes may significantly reduce the infiltration [3] of pollutants through the aeration zone to underground water.

7. The process of sulfide oxidation on the coal waste landfill "Debiensko" takes place in accordance with the range kinetics equation and for the first ten years of deposition for the deposited wastes it takes the following form: $\operatorname{Gs}(\mathrm{t})=0,01 \cdot \mathrm{e}-0,0005 \mathrm{t}$.

\section{References}

[1] Bzowski Z., Gwoździewicz M. Opracowanie prognozy jakości wód odprowadzanych ze zwałowiska kamienia przy KWK "Debiensko" po jego rekultywacji na podstawie badań wód drenażowych, odciekowych i deszczowych/Development of forecast of quality of water discharged from the stone dump at the KWK "Debiensko" after its reclamation, based upon test of rainwater, filtrate and drainage water/ Works of Central Mining Institute Katowice 1998 and 2003.

[2] Główny Urząd Statystyczny - Ochrona Środowiska, Warsaw 2006. 
[3] Kleczkowski A.S. Prędkość migracji zanieczyszczeń przez strefę aeracji na podstawie badań polowych i laboratoryjnych/Velocity of pollutants migration through the aeration zone based upon site and laboratory tests/ Krakow, AGH Department of Geology, Geophysics and Environment Protection 1999.

[4] Szczepańska J., Witczak S., and al. Kinetyka utleniania siarczków w strefie aeracji składowisk odpadów górniczych/Kinetics of sulfide oxidation in aeration zone of miting waste landfills/ I forum of ecological engineering, Lublin-Nałęczów 1996.

[5] Stefaniak S. Migracja zanieczyszczeń z warstwy odpadów górnictwa weglowego w środowisku wodno-gruntowym w różnych warunkach deponowania/Migration of pollutants from the layer of miting wastes in the water and soil areas in the various depositing conditions/ Praca doktorska 2006.

[6] Twardowska I. Mechanizm i dynamika ługowania odpadów karbońskich na zwałowiskach/Mechanizm and dynamic of carbonaceous waste leaching on the dumping yards/ Pr. I Stud. IPIŚ PAN, nr 251981. 